\title{
Az értelmiség új felelőssége a kommunikáció korában
}

Pierre Lévy a kollektív intelligencia és a digitális hálózatokban kibontakozó hipertextuális kommunikáció felől közelítve foglalkozik az értelmiség felelősségével a Le Monde Diplomatique magyar kiadásában megjelent rövid írásában, ami jelentős figyelmet váltott ki a magyarországi gondolkodók körében is. Cikkét különböző területeken működő neves hazai szakemberek kommentárjaival együtt közöljük újra, kis ajánlott olvasmánylistával kiegészítve a benne szereplő kulcsfogalmak hátterének megvilágítására az értelmiség társadalmi funkciói, a nooszféra és Lévy új metanyelve témakörében.

Kulcsszavak: az értelmiség felelőssége, hipertext, hálózatok, metanyelv, nooszféra

\section{Szerzői információ:}

Pierre Lévy

A kollektív intelligencia kutatásával foglalkozó tanszék vezetôje az Ottawai Egyetemen. Fő érdeklődési területe a kollektív intelligencia és a tudásalapú társadalom, valamint a kiberkultúra. Már 1990-ben, a web megjelenése elốtt egyik könyvében elốre látta a hipertextuális kommunikáció kibontakozását a digitális hálózatokban. 2004-ben a Kanadai Tudományos Akadémia tagjává választották. Kutatócsoportjával kifejlesztette az ,információ-gazdasági metanyelv” (Information Economy Meta Language, IEML) elnevezésú univerzális szemantikai címkézési rendszer alapjait. Fô múvei: L'Intelligence collective (1994), Cyberdémocratie (2002).

Így hivatkozzon erre a cikkre:

Lévy, Pierre. „Az értelmiség új felelőssége a kommunikáció korában”.

Információs Társadalom VIII, 4. szám (2008): 8-11.

$=$ https://dx.doi.org/10.22503/inftars.VIII.2008.4.1 $\rightleftharpoons$


Pierre Lévy

\section{Az értelmiség új felelóssége a kommunikáció korában}

Mennyiben változik az értelmiségiek felelőssége az új kommunikációs technológiák világában? Az általánosan elterjedt meghatározás szerint az értelmiség a gondolkodók olyan kategóriája, mely aktívan részt vesz a közügyek intézésében, és elvégzi a társadalom tudatos kritikáját. Csakhogy a nagy hozzáadott értékú tevékenységek elterjedésével, a felsőoktatás fejlődésével és az informatika, valamint az internet által serkentett interaktív, univerzális kommunikációs hálózat terjeszkedésével a történelmi látásmód a tudás világméretû́ társadalmára enged következtetni, melynek kritikai véleményét tömegesen fogják terjeszteni. Ebben az új helyzetben nem volna sürgôs újrafogalmazni az értelmiségiek szerepét?

Feladatunk elvégzése végett induljunk ki egy általános tényból: az emberi közösségek csak akkor élhetnek együtt, ha megegyeznek olyan szimbolikus rendszerekben, mint a nyelvek, az írás, az ismereteket rendszerezó tudományok, a technikai és szakmai hagyományok, az esztétikai értékek, a politikai intézmények, a vallási és jogi normák és így tovább. E szimbolikus rendszerek „,kultúrája” különbözteti meg az emberi fajt a közösségben élő állatfajoktól.

Az értelmiség legfóbb szerepe az, hogy tanulmányozza azokat a szimbolikus rendszereket, amelyekkel az emberi közösségek szimbiózist alkotnak, ôrködjék tagolódásuk, megfelelő múködésük és tökéletessé válásuk fölött. A kollektív intelligencia új világméretû kultúrájában ez a felelősség sürgetốbb, mint valaha. A mai értelmiségiek legfóképpen három kategóriába csoportosíthatók: a humán- és társadalomtudományok, a természet- és informatikai tudományok kutatói, valamint a kulturális örökségek átadói.

A 21. század elején az értelmiségiek hatalmas méretú kulturális változások elójeleivel szembesültek. Az emberiség szimbolikus termékeinek nagyobb része a legkülönfélébb szöveges, képi, hang-, zenei és szoftveres formában digitális dokumentumok révén érhetố el. Megszámlálhatatlanul sok, szimbólumokat feldolgozó - programokkal múködő - automatával rendelkezünk, melyek képesek arra, hogy hálózaton keresztül együttmúködjenek egymással a numerikus adatok tetszóleges szúrése, értelmezése és átalakítása érdekében. A digitalizált memóriák és a szimbólumokat feldolgozó számítógépes programok a világméretú kommunikációs hálózaton keresztül egyre gyorsabb összeköttetésben állnak egymással: ez a kibertér. Attól a pillanattól kezdve, hogy egy információ megjelenik valahol a hálózatban, az összeköttetések révén azonnal elérhetôvé válik. A digitális dokumentumok virtuálisan egy „hiperdokumentum” részét képezik, mely dinamikus, világméretú, folyamatosan gyarapszik, áttekinthetố és átalakítható a kibertérben jelenlevố intézmények és egyének összessége által. Ha az automatikus feldolgozás és a számítógépes programok együttmúködési képességét megszorozzuk a kibertér mindenütt jelenvalóságával és belső összeköttetésével, akkor a közös digitális memória képességét kapjuk meg. 
A 21. században az értelmiségiek egyik problémája éppen az, hogy a kollektív intelligencia kihasználása érdekében rátaláljanak eme új képesség legjobb felhasználási módjára. Új kihívásról van szó, mellyel egyik korábbi generációnak sem kellett szembenéznie. Ugyanakkor komoly akadályok tornyosulnak az előtt, hogy teljes egészében kiaknázhatók legyenek ezek az új lehetôségek.

Az akadályokat egymással összefüggő két alcsoportba lehet osztani. Az elsóbe a szimbolikus rendszerek sokfélesége és részekre darabolódásuk tartozik:

- a természetes nyelvek sokfélesége; a könyvnyomtatás korából örökölt indexelési és katalogizálási rendszerek sokaságának adaptálhatatlansága és kölcsönös összeegyeztethetetlensége az új rendszerrel (amit az összeköttetések felhasználásakor és a kibertér nagyságának kiszámításakor nem vettünk figyelembe), valamint

- a rendszertan, a fogalomtár, a terminológia, az ontológia és az osztályba sorolási rendszerek sokasága és összeegyeztethetetlensége (amely a kulturális, tradicionális, elméleti és tudományos különbségekból ered).

Az akadályok második alcsoportja azokat a nehézségeket foglalja magában, amelyekkel a számítógépes tervezés szembesül, amikor az általános módszerek eszközével próbálja meg értelmezni a dokumentumok jelentését. E tekintetben a legnyilvánvalóbb akadály a mai kereskedelmi keresốprogramok által alkalmazott módszerek viszonylagos hatástalansága akkor, amikor a rábízott feladat akár egy icipicit is bonyolult. Ne felejtsük el, hogy a Google vagy a Yahoo a világháló információtömegének mindössze 10-20 százalékában keres. Ezenkívül ezek az oldalak a kereséseiket karakterek láncolatára, nem pedig fogalmakra alapozzák. Ha például a felhasználó beírja a „kutya” keresőszót, akkor ezt a program a „k, u, t, y, a” karakterek sorozataként fogja fel, nem pedig több nyelvre lefordítható fogalomként (dog, chien, perro, kelb, cane...), amely példának okáért az emlősök és a háziállatok alrendjébe tartozik...

A keresőprogramok korlátain kívül a programtervezés azzal kínlódik, hogy megújítsa a fogalmait éppen akkor, amikor a kibertér használata terjed és diverzifikálódik. A 20. század végi nagy kreativitás fázisa után úgy túnik, a mesterséges intelligencia elvesztette vonzerejét. A nagyvállalatok (Yahoo, Google, AOL, IBM, Microsoft stb.) konzorciuma által irányított és több mint tíz éve útjára indított úgynevezett „szemantikai” web technikai kifinomultsága ellenére nem a várt fejlődést idézte elő. A mesterséges intelligencia és a szemantikai web ugyanattól a fejlốdési korláttól szenved: ragaszkodnak a logikai múveletek automatizálásához annak érdekében, hogy maximalizálják a számítógépek teljesítményét. Ez azonban csak a feladat egyik részét jelenti. A másik, még alig felfedezett rész a jelentésjelölés eredeti rendszereinek a kidolgozása, melyek a hálózaton levố kollektív intelligencia érdekében képesek kiaknázni az automatikus kezelés új lehetôségeit.

Összességében az információ és automatikus kezelési módjai az anyagi egységesülés felé haladnak az egész emberiség közös virtuális memóriájában, ámde ugyanúgy, mint ahogy a szemantikai korlátokat, a részekre széteséseket és összeegyeztethetetlenségeket csak nagyon részlegesen számolták fel, a kollektív intelligencia kiterjesztése - bármennyire is elốrehaladott már - még mindig alatta marad a lehetséges mértéknek. Kell-e ezen csodálkoznunk? Az elérhetô intelligens tudás kódolási 
rendszereinek óriási többségét még a kibertér létrejötte előtt találták fel és tökéletesítették. A világ lakossága számára nem egészen egy generáció óta érhetố csak el. Az új kulturális mátrix továbbra is befejezetlen. A 21. század értelmiségijei tehát azzal a problémával szembesülnek, hogy ki kell találniuk, adaptálniuk és tökéletesíteniük a szimbolikus rendszerek új nemzedékét, mely összhangban van a már rendelkezésre álló eljárás lehetőségeivel.

Azoknak az értelmiségieknek tehát, akik a kollektív intelligencia tökéletesítésének távlatában kiismerik magukat, folytatniuk kell a még befejezetlen új kulturális mátrix felállítását. Ezen összehangolt kezdeményezés egyik célja az emberi szellem szimbolikus természetének a gyakorlatilag végtelen kvalitatív változójú kozmosz formájában való bemutatása lenne, amely azonban matematikailag szervezett, vizsgálható, felderíthetô és beilleszthetô a kibertérbe. Ez az új intellektuális vállalkozás hozzájárulhat a humán tudományok feldarabolódási problematikájának a megoldásához, és lehetốvé teheti az egymással összefonódott társadalmaink hatékonyabb együttmúködését az emberi fejlődés érdekében. A természettudományok példája ebben a tekintetben irányt mutathat nekünk.

A 16. és a 20. század között a természettudományoknak egységes és végtelen fizikai terük volt, amely el volt látva univerzális mértékegységek szervezett és egységes rendszerével. Olyan világmindenséget fogadtak el, amelynek a változásait matematikai függvényekkel le lehetett írni. Napjainkban a természettudományok megfigyelési eszközei rendkívül fejlettek a tervezés szintjén, és állandóan továbbfejlődnek. A természettudományok metanyelve (vagyis a természetes nyelvek független szimbolikus és fogalmi eszközeinek az összessége) erốteljesen formalizált, logikailag koherens, és jelentôs mértékben elfogadják a tudományos közösségen belül. A matematikusoknak megvannak a maguk halmazai, összefüggései, számai és függvényei. A fizikusoknak megvan a maguk tömege, energiája és részecskéi. A vegyészek az elemeikkel, molekuláikkal és a reakcióikkal foglalatoskodnak. A biológusoknak ott vannak a biomolekuláik, DNS-ük, a sejten belüli és sejtek közötti anyagcsere-körforgásuk. Az elméletek megsokszorozódhatnak és különbözhetnek, de a metanyelv éppúgy, mint a matematikai koordináta-, mértékegység- és függvényrendszerek közösek maradnak, ami lehetôvé teszi a párbeszédet, a felfedezések ellenôrző tesztjét és tagolt felhalmozását. Az ismeretek kezelésével kapcsolatban azt lehet mondani, hogy a természettudományoknak sikerült tudásuk jelentôs részét explicitté, hozzáférhetôvé, múvelhetôvé és képessé tenni arra, hogy kölcsönös gyarapodásukat szolgálja.

Ezzel szemben a humán- és társadalomtudományoknak nincs közös kulturális univerzuma, egységes, végtelen, összehangolt, mérhetố és matematikai függvényekkel leírható nooszférája (a szimbolikus emberi tevékenységek összessége). A tudományágak továbbra is feldaraboltak. A tudományágakon belül a paradigmák konfliktusai gyakorta korlátozzák a gyümölcsöző vitákat. Még a véleménykülönbségek természetérôl is nehéz időnként egyezségre jutni. A megfigyelés eszközei a tervezés szintjén kevéssé fejlettek. A matematika egyik legfóbb eszköze a statisztika. Néhány magasan formalizált tudományágat (mint például a nyelvészet vagy a közgazdaságtan egyes ágait) kivéve az elméletek kiszámíthatósága, jóslási képessége és tesztelhetôsége gyenge. E helyzet legfóbb eredménye az, hogy a humántudomá- 
nyok kutató közössége által felhalmozott jelentôs tudás és szakértelem „implicit” marad, és nehezen terjeszthetô létrejötte kezdeti miliójétól különbözố környezetben. S mégis, az emberiség elốtt álló problémák megoldása azt kívánja, hogy a magas tudományok együttmúködjenek egymással.

Fordította: Ferwagner Péter Ákos 